УДК 349.2

\author{
I. В. Пiдnaла \\ orcid.org/0000-0002-1356-1160 \\ кандидат юридичних наук, \\ доиент кафедри загальних дисииплін \\ Медико-природничого університету
}

\title{
МОП - НАЙБІЛЬШИЙ РЕГУЛЯТОР ТРУДОВИХ ВІДНОСИН МОРЯКІВ
}

Виклад основного матеріалу. Серед дослідників міжнародного права існує думка, згідно якої суб'єктами трудового права є особи, які беруть i можуть брати участь у правовідносинах й бути носіями суб'єктивних трудових прав і обов'язків.

Міжнародним правовим статусом моряків є сукупність їхніх прав, свобод у державі, в якій вони працевлаштувалися. Проблеми їх правового статусу можна розбити на такі групи: колізійні питання громадянства; правове регулювання міжнародної міграції (в'їзд до держави, виїзд до інших держав); правовий статус українських моряків за кордоном. Міжнародні норми, присвячені правовому становищу моряків, можна об'єднати одним поняттям «право іноземців».

Особливість правового становища моряків як іноземців у тому, що на них одночасно поширюють свою дію кілька правопорядків:

- особистий закон іноземця - право держави, до якої належить моряк з огляду на його громадянство, постійне місце проживання;

- закон держави перебування (тієї країни, біля якої фактично перебуває моряк конкретний проміжок часу) [1].

Загальновизнаним поняттям «моряк» визнають людину, яка служить на флоті, або особу, яка має досвід у морській справі [2]. У зв'язку з цим визначення поняття «моряк» в розумінні «робітник» щодо розглянутого теоретичного питання в міжнародному трудовому праві є дуже цікавим. Деякі конвенції МОП визначають моряка як особу, яка фактично здійснює свої трудові функції, інші ж - як особу, здатну їх виконувати. Розглянемо це поняття більш детально на основі аналізу основних морських конвенцій МОП.

Так, Конвенція «Про працевлаштування моряків» № 9 від 10.07.1920 у термін «моряки» включає всіх осіб, які працюють як члени екіпажу судна, зайнятих у морському судноплавстві, за виключенням осіб командного складу [3]. При цьому Конвенція «Про трудові договори моряків» № 22 від 24.06.1926 і Конвенція «Про репатріацію моряків» № 23 від 23.06.1926 визначають термін «моряк» як певну особу, яка працює на борту будь-якого судна і записана до суднової ролі [4]. Конвенція «Про зобов'язання судновласників у разі хвороби, травми або смерті моряків» № 55 від 24.10.1936 застосовується до всіх осіб, які працюють на борту будь-якого судна, за винятком військових суден, зареєстрованих на території, для якої ця Конвенція чинна і використовується для морського судноплавства [5].

Конвенція «Про соціальне забезпечення моряків» № 70 від 28.06.1946, Конвенція «Про пенсії моряків» № 71 від 28.06.1946 і Конвенція «Про соціально-побутове обслуговування моряків у морі та в порту» № 163 від 24.09.1987 під терміном "моряк» визначають будь-яку особу, яка працює в різній якості на борту морського судна, яке є державною чи приватною власністю, виключаючи військовий корабель [6]. Конвенція «Про запобігання виробничим нещасним випадкам серед моряків» № 134 від 30.10.1970 визначила, що термін «моряк» охоплює всіх осіб, зайнятих будь-якою роботою на борту певного судна (за винятком військового судна), зареєстрованого на території, де чинна ця Конвенція, яке здебільшого використовується для морського плавання. У разі будь-яких сумнівів щодо того, чи вважаються які-небудь категорії осіб моряками згідно з метою цієї Конвенції, питання вирішує компетентна влада в кожній країні після консультацій із відповідними організаціями судновласників і моряків [7].

Конвенція «Про безперервність зайнятості моряків» № 145 від 28.10.1976 і Конвенція «Про щорічні оплачувані відпустки морякам» № 146 від 29.10.1976, Рекомендація «Щодо безперервності зайнятості моряків» № 154 від 28.10.1976 у своїх нормах термін «моряк» визначають як особу, яка працює за наймом на борту морського судна, зареєстрованого на території, на яку поширюється Конвенція, за виключенням військового корабля; судна, зайнятого риболовлею чи безпосередньо пов'язаними з нею операціями, або китобійним промислом чи аналогічними операціями [8].

Конвенція «Про соціальне забезпечення моряків» (переглянута) № 165 від 09.10.1987 говорить про те, що термін «моряк» означає особу, яка працює за наймом і виконує будь-які функції на борту морського судна, яке здійснює перевезення вантажів або пасажирів у комерційних цілях, використовується в будь-яких інших комерційних цілях або є морським буксиром [9]. Конвенція 
«Про найм і працевлаштування моряків» № 179 від 22.10.1996 під терміном «моряк» визнає будьяку особу, яка відповідає умовам працевлаштування або одержання роботи в будь-якій якості на борту судна далекого плавання, крім державного судна, яке використовується для військових або некомерційних цілей [10].

Конвенція «Про робочий час моряків і склад суднового екіпажу" № 180 від 22.10.1996 і Рекомендація «Щодо заробітної плати моряків, робочого часу та складу суднового екіпажу» № 187 від 22.10.1996 встановили, що термін «моряк» означає будь-яку особу, яка визначається національним законом, правилами або колективними угодами як така, що працює за наймом у будь-якій якості на борту такого судна далекого плавання, до якого застосовуються положення цієї Конвенції. Кожний член МОП в силу Конвенції може передбачати у своєму національному законодавстві такі виключення, які він вважає необхідними щодо риболовних суден [11].

Щоб стати моряком, насамперед необхідно, щоб настав встановлений законом вік, який у трудовому праві прописаний як вік настання правоздатності, що переплітається з віком дієздатності, тобто здатністю моряка своїми діями набувати, виконувати свої права та обов'язки. У статті 188 КЗпП передбачаються три варіанти початку трудової правоздатності за віком. Ані діюче в Україні трудове законодавство, ані проект Трудового кодексу України не мають нормативного визначення понять «трудова правоздатність» $\mathrm{i}$ «трудова дієздатність». При цьому з'явилася додаткова категорія, яка має важливе значення для поняття трудової правоздатності і дієздатності, «працездатність розуміюча» як здібність до трудової діяльності за станом здоров'я [12].

Щодо моряків як робітників працездатність має принципове значення при наймі на роботу. Наприклад, вимоги до стану здоров'я й інші специфічні вимоги до осіб, які входять до складу екіпажу морського судна, зумовлені об'єктивними умовами праці цієї категорії робітників. Моряк не може стати суб'єктом міжнародного морського трудового права, якщо не володіє працездатністю, тобто не придатний до виконання трудової функції як члена екіпажу судна за станом здоров'я. Трудова правоздатність і дієздатність моряків мають низку особливостей порівняно з іншими категоріями робітників. Наприклад, до роботи на морі можуть бути допущені особи не молодші 16 років (у цьому випадку українське законодавство відповідає міжнародними нормам), які мають фізичну підготовку, володіють знанням англійської мови, а також пройшли відповідну професійну підготовку і навчання та мають відповідний диплом, сертифікати та паспорт моряка [13].
Таким чином, моряк як суб'єкт міжнародного права є носієм міжнародних прав та обов'язків, які виникають згідно з загальними нормами міжнародного права або приписами міжнародно-правових актів. Моряком як суб'єктом міжнародного трудового права вважаються такі носії прав і обов'язків у сфері міжнародного правового регулювання трудових відносин, якщо вони є учасниками таких відносин в силу свого міжнародно-правового статусу. Відомо, що насамперед до суб'єктів міжнародного трудового права належать держави, об'єднання держав і міжнародні організації. Міжнародно-трудова правосуб'єктність держав, наприклад, визначається обсягом їхніх прав і обов'язків як суб'єктів міжнародного права взагалі і є частиною міжнародної правосуб'єктності. Важливим для визначення їхнього правового статусу є право останніх брати участь у міжнародному співробітництві з будь-яких питань, що складають міжнародний інтерес, та обов'язок забезпечувати і дотримуватися належного рівня гарантування та захисту основних прав і свобод для моряків на відповідній території, що водночас $є$ і основними принципами сучасного міжнародного права.

Як суб'єкти міжнародного трудового права держави мають право реалізувати свої інтереси у сфері праці, трудової міграції, соціального забезпечення шляхом укладення міжнародних договорів на дво- та багатосторонній основі; вони мають право брати участь у діяльності міжнародних організацій з універсальним і спеціальним статусом та у прийнятті останніми правових приписів щодо правового регулювання праці та трудових відносин; їм надано право об’єднуватися і виробляти спільні рішення в цій сфері на регіональній основі. Держави за способом набуття прав та обов'язків володіють первинною, а за змістом і обсягом належних їм прав - загальною та договірною правосуб'єктністю, що містить і ознаки універсальності. Вони виявляються у тому, що держава лише за фактом її існування зі всіма необхідними атрибутами державності автоматично набуває статусу суб'єкта міжнародного права з усією сукупністю міжнародних прав та обов'язків, в тому числі і у сфері праці та трудових відносин.

3 метою набуття додаткових прав та обов'язків, розширюючи межі правосуб'єктності, держава вступає у договірні стосунки з іншими державами, об'єднаннями держав і міжнародними організаціями, метою яких є узгодження інтересів у визначеній сфері та вироблення єдиних підходів, принципів, стандартів до правового регулювання праці та трудових відносин. Усі міжнародні заходи, які стали предметом угод і домовленостей, здійснюються не безпосередньо, а через державу. Тільки вона бере на себе відповідні міжнародно-правові зобов'язання щодо охорони трудових 
прав індивідів. Тобто лише вольовий акт верховної державної влади, яким ратифікуються відповідні міжнародні угоди з питань праці, надає дієвості відповідним положенням міжнародних актів. Тому, володіючи всією сукупністю прав, держава насамперед виходить із власних інтересів і виявляє волю щодо їх реалізації в конкретних договірних взаємовідносинах. Загалом подальша реалізація зумовлених договірних взаємовідносин так само залишається прерогативою держави і пов'язується з подальшою їх ратифікацією й наданням таким домовленостям юридичної сили в межах своєї юрисдикції [14].

Крім зазначених вище трудових відносин, у міжнародному трудовому праві можуть виникати й інші відносини. У випадку, якщо суб'єктами таких відносин стають міжнародні організації (наприклад, МОП), то такі відносини будуть похідними від трудових відносин. Таким чином виявляється необхідність проаналізувати правовий статус міжнародних організацій, які займаються питаннями праці, їхню правосуб'єктність і роль у правовому регулюванні праці, а також ефективність їхньої діяльності [15].

У міжнародних організаціях склад нормотворчої діяльності визначається наявністю дійсно насущних потреб усіх світових товариств щодо регулювання трудових відносин на сучасному етапі розвитку економічних відносин людської цивілізації. Це сприяє забезпеченню процесу взаємодії міжнародного і внутрішньодержавного права, яке може бути як міжнародно-правовим, так і національно-правовим [16]. Як вбачається з історії, необхідність формалізувати старі звичаї виникла в законодавстві у XIX ст. при міжнародному підході до вирішення проблем. Із середини цього століття почали з'являтися нормативні акти, які встановлювали правила поведінки держав в області функціонування міжнародної організації. Першими з таких документів були регламенти річкових комісій по Рейну і Дунаю, що регулювали річкові перевезення.

3 давніх часів бурхливий ріст міжнародної торгівлі сприяв швидкому розвитку мореплавства, яке часто закінчувалося катастрофами, оскільки не існувало правил керування водними просторами. Наприклад, всередині XIX ст. біля берегів Франції щорічно зазнавали катастроф у середньому біля 180 суден різних націй. Германських суден далекого плавання у період із 1886 по 1897 рік потонуло близько 1128. Щодо морів світу, то вкінці XIX ст. зазнали катастроф 1830 суден, із яких 899 вдалося врятувати, а 931 - ні [17].

У 1945 році з'явилася міжнародна організація ООН, яка приділяла проблемам мореплавства ретельну увагу. Через три роки після їі творення в Женеві була скликана міжнародна конференція і прийнята Конвенція «Про створення Міжнарод- ної морської організації». Основною її задачею стало встановлення правил, які стосуються судноплавства в області забезпечення безпеки на морі та регулювання міжнародних відносин.

У 1974 році була прийнята Міжнародна Конвенція «З охорони людського життя на морі» (далі - СОЛАС), до якої приєдналося 120 держав із понад 98\% усіх суден, відомих у світі. Це свідчить про роль IMO, як нормотворчого органу, який захищає моряків як суб'єктів міжнародних відносин. Що ж стосується конвенцій, то вони широко визнаються, оскільки нині не можливо керувати судном по міжнародних маршрутах, не враховуючи правил IMO, які регулюють рух на морі. Нині перед IMO стоять задачі, які вона покликана вирішити в сукупності для забезпечення безпеки судноплавства в міжнародних масштабах, найважливішими з них є задачі, пов’язані з екіпажом, оскільки моряки, які знаходяться на борту суден як члени екіпажу, повинні бути під особливою увагою, тому що нещасні випадки 3 ними виникають значно частіше, ніж технічні збої в роботі машин.

Глобальна роль IMO найбільш виражено виявляється в універсальному розробленні нею інструментів та правил для забезпечення безпеки мореплавства. Так, була здійснена розробка Міжнародної конвенції «Про пошук і рятування на морі» від 27.04.1979, яку ратифікувало 56 держав, флот яких складає 98,3\% світового тоннажу, Міжнародної конвенції «Про вантажну марку» від 05.04.1966, яку ратифікувало понад 60 держав, флот яких складає 98,2\% світового тоннажу та Міжнародної конвенції «По запобіганню забрудненню з суден» від 02.11.1973, яку ратифікувало понад 50 держав, флот яких складає 93,4\% світового тоннажу. При активній участі IMO прийняті такі основні джерела міжнародного морського права, як Конвенція ООН «Про відкрите море» від 29.04.1958 і Конвенція ООН «Із морського права» від 10.12.1982 [18].

У 1959 році IMO підписала угоду з МОП, проголосивши необхідність тісної співпраці і проведення консультацій щодо питань, які являють спільний інтерес. Безпосередня співпраця двох організацій почалася з 1964 року, коли був створений Об'єднаний Комітет МОП/IMO з метою перевірки підготовки моряків до вміння використання навігаційних засобів й іншого обладнання, спрямованого на забезпечення безпеки на морі належним чином [19].

МОП є найбільшим у світі регулятором трудових відносин. Нині її учасниками є понад 170 держав, в яких мешкає 98\% населення світу, наша країна також є учасником. Практика діяльності МОП свідчить про те, що головна мета міжнародно-правового регулювання праці полягає в сприянні покращенню умов праці для суб'єктів трудо- 
вих відносин. У роботі МОП беруть участь не лише представники держав, як це відбувається в звичайних міжнародних організаціях, але й представники працюючих і підприємців, при чому усі вони володіють однаковим правом голосу. Нині цей організаційний принцип втілився в систему соціального партнерства не тільки на міжнародному рівні, але і у національному законодавстві та практиці.

Головна мета діяльності МОП сформована в преамбулі до їі Статуту - забезпечення загального і міцного миру на основі соціальної справедливості. Для цього існують змішані міжнародні договори, які містять по два види зобов'язань: 1) міжнародно-правові між державами й іншими суб'єктами міжнародного права; 2) цивільно-правові й інші не міжнародно-правові зобов'язання між державами й не суб'єктами міжнародного права. Участь не суб'єктів міжнародного права в деяких категоріях міжнародних договорів не позбавляє останніх міжнародно-правового характеру.

Особливе місце серед міжнародно-правових актів у сфері праці займають Конвенції та рекомендації МОП, оскільки вона є спеціалізованою установою $\mathrm{OOH}$, яка проголосила за мету вивчення й поліпшення умов праці та життя працівників. Тому найважливішою стороною діяльності МОП $є$ розробка та прийняття конвенцій і рекомендацій. Саме можливість відкритого висування й обговорення вимог щодо створення міжнародних правових актів і норм певною мірою слугує поліпшенню умов праці та умов життя працюючих. Ці нормативи про працю є тими основними формами, за допомогою яких МОП здійснює міжнародно-правове регулювання праці. Своїми конвенціями МОП створює для держави, яка їі ратифікувала, зобов'язання щодо внесення відповідних змін до національного законодавства про працю, а рекомендаціями закликає держави, щоб національні норми трудового права по можливості відповідали нормам, закріпленим у рекомендаціях [12].

3 моменту створення МОП було вирішено, що особливі питання, які відносяться до моряків, слід розглядати на спеціальних морських сесіях Міжнародної конференції праці, присвячених виключно їхнім проблемам. Так, у період між 1920 і 2012 роками МОП прийняла понад 45 Конвенцій (в силу вступило більше 39) і 36 Рекомендацій, які стосуються моряків як суб'єктів міжнародного права, що складають чверть від загальної кількості нормативних актів МОП [20].

На морському флоті МОП веде постійну роботу в області правового регулювання праці моряків:

1) розробляє конвенції та рекомендації й інші нормативні акти стосовно праці моряків;

2) співпрацює в рамках своєї компетенції з різних питань із IMO та іншими міжнародними організаціями з метою підвищення безпеки судноплавства. Вони на своїх сесіях приймають низку найважливіших міжнародних конвенцій, резолюцій, кодексів і рекомендацій, спрямованих на забезпечення безпеки мореплавства й охорону довкілля. Основна мета цих документів - підвищення безпеки мореплавства шляхом обов'язкового застосування єдиних для усіх встановлених стандартів як при управлінні суднами з берега, так i в процесі їх експлуатації екіпажами;

3) розробляє міжнародні правила і програми навчання осіб морським спеціальностям, приділяючи особливу увагу навчанню плавскладу протипожежним прийомам і правилам безпеки мореплавства;

4) контролює соціальне обслуговування моряків судновласниками;

5) надає допомогу при потраплянні суден в аварію;

6) розробляє правила щодо запобігання піратським нападам;

7) контролює умови трудових договорів та облік їх робочого часу і відпочинку, занесених до судових графіків роботи [2]. Відсутність реального механізму забезпечення виконання державами-членами організації прийнятих на себе обов'язків в області регулювання праці моряків можна віднести до недоліків роботи МОТ. Заради справедливості потрібно зазначити, що такий недолік властивий не лише МОП, але й багатьом іншим міжнародним міжурядовим організаціям і навіть всьому міжнародному праву загалом [19].

У статуті МОП від 28.06.1919 (ст. 33) передбачено примушувати держави до виконання зобов'язань: «Якщо який-небудь Член Організації не підкориться в зазначений час рекомендаціям, які містяться в докладі комісії по розслідуванню чи в рішенні Міжнародного Суду, то Адміністративна Рада може рекомендувати Конференції такі дії, які вирішить доцільними для забезпечення виконання цих рекомендацій” [20]. Безумовно, такий механізм реалізації норм не може діяти ефективно. Тому настав час для внесення відповідної законодавчої норми, яка забезпечить можливість застосовувати більш впливовіші примусові заходи. Нині єдина санкція, допустима МОП, це моральна. Вихід із цієї ситуації вбачається в більш чіткій послідовності вимог, які входять до компетенції міжнародних організації, а також більш відповідальному виконанні угод про розмежування повноважень між організаціями й державами.

Розглядаючи діяльність міжнародних організацій, не можна не зазначити проблему належного здійснення їхніх приписів щодо усунення порушень на практиці. Часто діяльність держав по виконанню припису не ефективна, оскільки в багатьох із них норми, створені міжнародними організаціями в цій сфері, просто не діють. Тому необхідно цілеспрямовано відновити організаційно-правовий механізм діяльності держав в рамках 
міжнародних організацій з метою своєчасної, всебічної і повної реалізації прийнятих ними зобов' язань по забезпеченню ефективності дії норм міжнародного трудового права.

Зі сторони міжнародних організацій необхідно посилити контроль за забезпеченням безпеки праці на морі та соціальним захистом моряків як у кожній країні, так і в світовій галузі судноплавства загалом. Такі дії дадуть змогу контролювати не тільки наявність фактів порушення безпеки мореплавства, але й створить на основі вивчення відповідної інформації підстави для винесення необхідних і конкретних рекомендацій державам по ліквідації порушень, 3'явиться можливість контролю за додержанням цих рекомендацій щодо моряків [12].

Висновки. Таким чином, держави, міжнародні організації та моряки виступають суб'єктами міжнародного трудового права. Моряки як суб'єкти трудового права, працевлаштовуючись до іноземного судновласника у певній державі, створюють своїми діями трудові правовідносини, які підлягають регулюванню, що зобов'язує вступати у свої права міжнародні організації для виконання повноважень щодо регулювання та контролю трудових відносин між державами та моряками як суб'єктами.

Моряки як суб'єкти мають володіти трудовою правосуб’єктністю, а саме правоздатністю, дієздатністю і працездатністю, тобто стосовно міжнародного морського трудового права вони повинні відповідати спеціальним вимогам щодо віку, кваліфікації, професійної підготовки й стану здоров' я. Згідно з цим судновласники наділені відповідними договірними правовідносинами, за допомогою яких вони користуються правом підбору, найму та звільнення моряків. Держави як основні діючі суб'єкти у цих міжнародних трудових відносинах у результаті волевиявлення формують міжнародно-правові норми для здійснення трудових відносин між судновласником і моряком, а міжнародні організації, насамперед МОП, як органи, які приймають конвенції й рекомендації про працю на основі аналізу правовідносин, що склалися, з урахуванням національного законодавства відповідно до волевиявлення держав і локальних актів судновласників регулюють і контролюють додержання усіх нормативів цими суб'єктами.

Моряки є одним з елементів створення міжнародних трудових відносин, в яких вони виступають як суб'єкти цих правовідносин, що підпадають під законодавчі норми держави, в якій вони працевлаштовуються, а держава щодо них є керу- ючим суб’єктом праці. Міжнародні ж організації щодо моряків є захисним, стосовно держав - контролюючим, а щодо їх обох - регулюючим суб’ $є$ том праці у міжнародній трудовій системі.

\section{Jimepamypa}

1. Фельдман Д.И. Международная правосубъектность: некоторые вопросы теории // Под редакцией Д.И. Фельдмана. М., 1971. С. 14.

2. Шемякін О.М. Міжнародне приватне морське право. Одеса : ЛАТСТАР, 2000. 272 с.

3. Маврин С.П., Хохлов Е.Б. Работник как субъект трудового права. Правоведение. 1996. № 4.

4. Гайворонський В.M. Міжнародне приватне право : навч. посібник / За ред. В.М. Гайворонського, В.П. ЖУшмана. К. : Юрінком Інтер, 2007. 368 с.

5. Скобелкин В.Н. Трудовые правоотношения / В.Н. Скобелкин. М., 1999. 152 с.

6. Лазор Л.И. Трудовые правоотношения. 2011. URL: dspace.snu.edu.ua:8080.../109/.._187.pdf.

7. Фізичні особи як суб'єкти МПП. URL: http://http://librar.org.ua/sectionsr_46203.html.

8. О’Нил Уильям А. ООН и Международная морская организация. Московский журнал международного права. 1996. № 2. С. 94-99.

9. Иванов С.А. Проблемы международного регулирования труда / С.А. Иванов. М., 1964. С. 15.

10. Иванов С.А. МОТ: контроль за применением международных норм о труде и его проблемы / С.А. Иванов // Государство и право. 1997. № 7. С. 22.

11. Статут Міжнародної організації праці. URL: https://zakon.rada.gov.ua/laws/show/993_154\#Text.

12. Дженис М. Европейское право в области прав человека. [Практика и комментарии] / Дженис М., Кэй Р., Бродли Э.: пер. с англ. М. : «Права человека», 1997. $640 \mathrm{c}$.

13. Гаврилов В.В. Международное частное право. 2- е изд., перераб. и доп. М., 2002. С. 26-73.

14. Ануфриева Л.П. Международное частное право. Общая часть. М., 2000. Т. 1. С. 122-167.

15. Международное гуманитарное право в документах. М. : Московский независимый институт международного права, $1996.556 \mathrm{c.}$

16. Лукашук И.И. Международное право. Общая часть : учебник. М., 1996. 152 с.

17. Игнатенко Г.В., Туинов О.И. Международное право : учебник для вузов. М., 2001. С. 25-41.

18. Сборник правових актов МОТ / Сост., предисловие докт. юрид. наук, проф. эксперта комитета экспертов МОТ С.П. Маврина. СПб : Изд-во Р. Асланова «Юридический центр Пресс», 2004. 485 с.

19. Жернаков В. Міжнародний аспект правового регулювання соціально-трудових відносин. Право України. 2001. № 4. С. 59-61.

20. Лаврінчук I. Європейська конвенція і трудове право України. Праия $і$ зарплата. 2004. № 18. С. 2-3.

21. Кауров В.Г. Международное трудовое право отрасль международного права. Знания молодых юристов XXI века : материалы научной конференции студентов, аспирантов и молодых ученых. Владивосток., 2001. C. 106-111. 


\section{Анотація}

Підпала I. B. МОП - найбільший регулятор трудових відносин моряків. - Стаття.

Правосуб́'єктність міжнародних організацій є похідною від правосуб'єктності держав, оскільки за своїм характером, змістом та обсягом повністю залежить від волі держав. Проте за способом набуття прав та обов'язків міжнародно-трудова правосуб'єктність міжнародних організацій $€$ договірною, оскільки сукупність прав і обов'язків щодо правового регулювання питань праці та трудових відносин виникае на підставі багатосторонніх договорів. Внесення загального поняття «моряк» у відповідні конвенції МОП має велике значення і тлумачиться як особа, визначена національним законодавством чи практикою або колективними угодами, яка бажає працевлаштуватися чи працювати за наймом як член екіпажу на борту морського судна, за виключенням військового корабля; судна, зайнятого рибальством чи безпосередньо пов'язаних з ним операціями, чи китобійним промислами або аналогічними операціями.

Практика застосування Міжнародних Конвенцій МОП в Україні свідчить про те, що деякі норми тлумачяться розширено і застосовуються не лише до моряків, але й до членів екіпажів рибопромислових суден. Насамперед це стосується норм про заробітну плату, тому правове регулювання діяльності моряків МОП є дуже впливовим механізмом і захищає трудові права членів екіпажів.

Зроблено висновок, що держави, міжнародні організації та моряки виступають суб'єктами міжнародного трудового права. Моряки як суб'єкти трудового права, працевлаштовуючись до іноземного судновласника у певній державі, створюють своїми діями трудові правовідносини, які підлягають регулюванню, що зобов'язує вступати у свої права міжнародні організації для виконання повноважень щодо регулювання та контролю трудових відносин між державами та моряками як суб'єктами. Моряки при цьому як суб'єкти мають володіти трудовою правосуб'єктністю, а саме правоздатністю, дієздатністю і працездатністю, тобто стосовно міжнародного морського трудового права вони повинні відповідати спеціальним вимогам щодо віку, кваліфікації, професійної підготовки і стану здоров'я. Згідно з цим судновласники наділені відповідними договірними правовідносинами, за допомогою яких вони користуються правом підбору, найму та звільнення моряків.
Ключові слова: міжнародна організація праці, міжнародні конвенції, трудові відносини, моряк, національне законодавство, колективні угоди.

\section{Summary}

Pidpala I. V. ILO largest control of labor relations sailors. - Article.

The legal personality of international organizations is a derivative of the legal personality of states, since by its nature, content and volume it completely depends on the will of the states. However, according to the method of acquiring rights and obligations, the international labor legal personality of international organizations is contractual, since the set of rights and obligations regarding the legal regulation of labor issues and labor relations arises on the basis of multilateral agreements. The introduction of the general concept of a seafarer in the relevant ILO conventions is of great importance, and is explained by a "seafarer", as a person defined by national law or practice, or by collective bargaining agreements, wishing to be employed or employed as crew members on board a sea vessel, for with the exception of: a warship; a vessel engaged in fishing or directly related operations, or whaling or similar operations.

The practice of applying the International Conventions of the ILO in Ukraine indicates that some norms are being expanded and applied not only to seafarers, but also to crew members of fishing vessels. First of all, this concerns the norms on wages therefore, the legal regulation of the activities of the ILO seafarers is a very influential mechanism and protects the labor rights of crew members. It is concluded that states, international organizations and seafarers are subjects of international labor law.

Seafarers, as subjects of labor law by employment with a foreign shipowner in a particular state, create by their actions an employment relationship that is subject to regulation, which obliges international organizations to enter into their rights to exercise powers to regulate and control labor relations between states and seafarers subjects. Seafarers, as subjects, must have legal personality, namely legal capacity, capacity and ability to work, ie in relation to international maritime labor law, they must meet special requirements regarding age, qualifications, training and health status. According to this, shipowners are endowed with appropriate contractual legal relations, through which they enjoy the right to select, hire and release seafarers.

Key words: international labor organization, international conventions, labor relations, seafarer, national legislation, collective agreements. 